\title{
HENKILÖSTÖN KEHITTÄMINEN JOHTAMISTOIMINNAN OSANA
}

Hyvin koulutetusta ja dynaamisesta henkilöstöstä kilpaillaan työelämässä sekä yksityisellä sektorilla että julkisessa hallinnossa. Erityisesti asiantuntijatehtävissä toimivien spesialistien merkitys työelämässä on korostunut. Kuilu pysähtyneen henkilökunnan ja dynaamisen henkilökunnan omaavien organisaatioiden välillä kasvaa. Menestyksen mahdollisuuksia ilman vireää ja tehtäviensä tasalla olevaa ammattiväkeä ei ole, kirjoittaa Ritva Jakku-Sihvonen artikkelissaan.

Kirjoittaja esittää henkilöstön kehittämistehtävissä toimiville yleisiä henkilöstön kehittämisperiaatteita.

Henkilöstön kehittämisestä on tullut työelämässä menestystekijä. Syitä tähän on monia. Uudistuvan tiedon merkitys elämän kehittämisessä on kiistaton. Kehittyvät mahdollisuudet uusimman kotimaisen ja ulkomaisen osaamisen hyväksikäyttöön kasvattavat jatkuvasti niiden yrityksien ja organisaatioiden menestymisen mahdollisuuksia, joissa henkilöstö on kehityshakuista ja kykenevää hyväksikäyttämään mahdollisimman laajasti oman erityisalansa tietämystä.

Vanhastaan johtaminen on jaettu asiajohtamiseen (management) ja ihmisten johtamiseen (leadership). Asioiden johtaminen ja ihmisten johtaminen eivät enää käytännön työssä ole yhtä kaukana toisistaan kuin aiemmin oli asianlaita. Pyrkimys mataliin toimintayksiköihin pois moniportaisista linjaorganisaatioketjuista tekee myös mahdottomaksi kovin korostaa asia- ja ihmisjohtamis- toimien erilaisuutta. Aiemminhan esimerkiksi johtamiskoulutuksessa nimenomaan linja esimiesten koulutuksessa ihmisten "käsittelytaito" oli korostuneesti esillä. Toimintalinjoista päättämiseen, taloudelliseen johtamiseen ja strategioista tehtävään päätökseen valmistaminen oli korkeimpien johtajien koulutuksen keskeisiä sisältöalueita.

Tulosjohtamisen laaja hyödyntäminen suomalaisessa työelämässä pakottaa jokaisen vastuullisen johtajan kouluttautumaan monipuolisesti. Tuloksekkaasti ei voida odottaa toimivan sellaisten johtajien ja asiantuntijoiden, joille yksikön toiminta-ajatus ja osaamisen tietoperusta on vieras. Toimintastrategia on vasta sitten tuloksekas kun se on kaikkien organisaation jäsenten sisäistämä, ja henkilöstön käytössä on tuloksen tekoon soveltuva keinovalikoima. 


\section{Henkilöstö johtamisen strategiassa}

Strategisella johtamisella tarkoitetaan sitä johtamistoiminnan aluetta, jonka tarkoituksena on luoda toimintapolitiikkaa ja asettaa toiminnan päämääriä yrityksen tai organisaation luodessa itselleen asemaa toimintaympäristössä. Strategisen johtamisen merkitystä ovat korostaneet elinkeinoelämän johtamisen asiantuntijat vanhastaan $(\mathrm{mm}$. Anthony 1965).

Henkilöstön mieltäminen osaksi strategista johtamistoimintaa merkitsee käytännössä sitä, että henkilöstön hankintaan, koulutukseen, viihtyvyyteen ja urakehitykseen kiinnitetään laajaa huomiota (vrt. Vanhala 1985,5).

Nimenomaan henkilöstön kehittäminen on noussut strategisen johtamisen keskeiseksi funktioksi. Johtamistoiminnassa henkilöstöpolitiikka ja henkilöstön kehittäminen kietoutuvat yhteen monella tapaa. Käytän. nön mahdollisuudet itsensä kehittämiseen edellyttävät henkilöstöhallinnollisia järjestely. jä ja joustavuutta, joiden kehittäminen edellyttää aikaansa seuraavan kehityshakuisen johdon toimenpiteitä.

Hyvin koulutetusta ja dynaamisesta henkilöstöstä kilpaillaan työelämässä sekä yksityisellä sektorilla että julkisessa hallinnossa. Erityisesti asiantuntijatehtävissä toimivien spesialistien merkitys työelämälle on korostunut. Kuilu pysähtyneen henkilökunnan ja dynaamisen henkilökunnan omaavien organisaatioiden välillä kasvaa. Menestyksen mahdollisuuksia ilman vireää ja tehtäviensä tasalla olevaa ammattiväkeä ei ole. Jo nyt on näyttöä siitä, että jähmettynyt ja kangistunut hallintorutiinikaan ei kykene estämään niiden virkkujen toimintaa, jotka kykenevät kehittämään esimerkiksi julkishallintoa uusien työmenetelmien ja tietovarantojen hyväksikäytön turvin.

Henkilöstöpolitiikastaan johtuen on julkishallinnossa henkilöstön kehittämiselle virinnyt erityisvaatimuksia. Huomionarvoisinta on se, että nykyoloissa etenkään julkinen hallinto ei voi vaihtaa henkilöstöä yhtä nopeatempoisesti, kuin toimintalinjojen kehittämisen kannalta väliin haluttaisiin tehdä. Myös elinkeinoelämä on käytännössä hyvin sidottua henkilöstöönsä: pitkälle erikoistuneiden ammattihenkilöiden saaminen muuttuvissa oloissa yrityksen palvelukseen ei aina ole helppoa.
Työelämässä hyvästä henkilöstöstä kilpailtaessa eivät kilpailuvaltteina ole enää yksin palkka ja luontaisedut vaan työn sisältö ja jatkuva mahdollisuus kehittymiseen on tärkeitä kriteereitä huippuasiantuntijoille. Viime mainittu seikka osaltaan lisää hyvän henkilöstönkehittämisstrategian merkitystä.

\section{Henkilöstön kehittämisen merkitys korostuu}

Henkilöstön kehittäminen strategisen johtamisen alueena ei toistaiseksi ole saanut suomalaisessa julkishallinnossa yhtä suurta jalansijaa, kuin mikä sillä on esimerkiksi suuryrityksissä länsimaissa. Nopeatempoiset muutokset työelämässä vaativat henkilöstöltä valmiutta uuden tiedon omaksumiseen, mikä edellyttää organisaatiolta jatkuvaa panostusta henkilöstön oppimishalukkuuden ylläpitämiselle.

Organisaatioon ja työhön sitoutumisen lisääntyminen mielekkäiden työtehtävien ja dynaamisen toimintamiljöön omaavilla työpaikoilla on yksi kannustin myös aikaa ja voimia kysyvään oman ammattipätevyyden kehittämiseen. Noe (1986) toteaa, että työmotivaatioltaan hyvät, organisaatioonsa sitoutuneet ihmiset ovat oppijoinakin työtovereitaan tehokkaampia.

Henkilöstön kehittämisen mahdollisimman hyvä valmiustaso on tunnusomaista menestyvälle organisaatiolle. Organisaation hierarkian kaikilla tasoilla on henkilöstön kehittäminen merkityksellistä. Johtajiston kehitykseen keskittyvä yritys elää tekohengityksen varassa.

Tämän päivän haastavin kohderyhmä henkilöstökoulutuksen kannalta on työelämän asiantuntijajoukko. Asiantuntijat tekevät merkittävää tuotekehittely-, suunnittelu-, valmistelu- ja esittelytyötä. Johtamistoiminnassa tulisi erityistä huomiota kiinnittää asiantuntijajoukon täydennyskoulutukseen ja uutta pätevyyttä luovaan koulutukseen.

Henkilöstökoulutuksella on johtamisen strategiassa monentasoisia tehtäviä. Henkilöstön kehittämisen lähtökohtana tuleekin olla linjakas ja selkeästi ilmaistavissa oleva toimintapolitiikka. Henkilöstön kehittämiseen kuuluu se, että kaikki työntekijät perehdytetään (mutta viisaassa organisaatiossa ei sopeuteta!) organisaation toimialaan ja toimintaperiaatteisiin sekä vallitsevaan organisaatiokulttuuriin. 
Toimintalinjoihin perehdyttämisen tulee olla vuosittaista: ei vain uudet työntekijät vaan myös vanhat työntekijät tarvitsevat ajantasalla olevaa sisäistä tietoa siitä, miten esimerkiksi oman yksikön toimintapolitiikka vastaa koko organisaation toimintapolitiik. kaa. Tämä toiminta on useissa organisaatioissa nähty sisäisen tiedotuksen tehtäväksi ja raja onkin väliin hämärä.

Silloin, kun on suuria painoalueiden tai toimintastrategioiden muutoksia, tarvitaan perusteellista koulutusta. Esimerkiksi uusien tulostavoitteiden ja niiden saavuttamisen tähtäävien toimien käyttöönotto edellyttää usein siinä määrin uusia ajatusmuotoja, toimintamalleja ja käytännön taitoja, että useimmat työntekijät kaipaavat lisävalmiuksia luovaa koulutusta.

Erikoisen ongelmallista on uutta luovan pätevyyden kehittämisen kannalta tuloksekkaiden toimintamallien luominen työelämän aikuiskoulutuksen käyttöön. Liian ahtaasti määritellyt henkilöstön kehittämisen ehdot ovat usein rajoittaneet yksilöllisten opiskeluintressien hyödyntämismahdollisuuksia.

Henkilöstön kehittäminen strategisen johtamisen osana edellyttää organisaatiossa käytännön toimia. Jotta henkilöstön kehittämisellä voitaisiin tuottaa sellaista osaamista, joka vastaa moderniin johtamiseen liittyviä odotuksia, tulisi henkilöstön kehittäjän noudattaa ainakin seuraavat periaatteet:

1. Panosta yksilölliseen ammatillisen pätevyyden kehittämiseen. Oman pätevyy. den kehittämismahdollisuus motivoi kaikilla tasoilla työskenteleviä henkilöitä. Kiinnitä erityistä huomiota asiantuntija. tehtävissä toimivien uutta luovan pätevyyden hankintaan.

2. Varmista koulutuksen keinoin, että jokainen organisaatiosi jäsen on tietoinen keskeisistä tavoitteista ja organisaation toiminta-ajatuksesta. Tarjoa jokaiselle työyhteisön jäsenelle mahdollisuus työryhmissä omien kehittämisideoidensa ja kritiikkinsä esille tuomiseen ja organisaation toiminta-ajatusta kehittävään keskusteluun. Tämä prosessi luo yksilöille edelly. tyksiä kehittää omaa työorientaatiotaan ja oman osaamisensa kehittämistavoitteita.

3. Huolehdi, että organisaatiossa on koko ajan meneillään ainakin yksi kehittämis. hanke, jossa työkäytäntöjä uudistetaan. Varaa kehittämishankkeisiin osallistujille tilaisuus hankkeen kuluessa tutustua asi- aan liittyvään kehittämistyöhön kotimaisissa ja ulkomaisissa kohteissa.

4. Luo organisaatioon strategisen toimintasuunnitelman yhteyteen erillinen henkilöstön kehittämissuunnitelma ja huolehdi sen toteutuksesta ja seurannasta.

5. Tutki henkilöstön halukkuus tavoitteelliseen itsensä kehittämiseen ja luo opiskeluun yksilölliset edellytykset. Venytä henkilöstöhallinnollisten toimien rajoituksia vastaamaan uusia tarpeita.

6. Kannusta jokaista omaehtoisesti opiskelevaa.

7. Huolehdi siitä, että organisaatiosi henkilöstöllä on jatkuvasti käytössään ajankohtaista tietoa organisaatiosi ulkopuolisesta kotimaisesta ja ulkomaisesta alan koulutustarjonnasta asiantuntemusalueittain, ammattiryhmittäin ja työryhmittäin.

8. Kannusta henkilöstöä kehittämään myös yleissivistäviä valmiuksia. Kielikoulutus ja kulttuurien tuntemukseen tähtäävä koulutus on pitkällä tähtäimellä myös organisaatiosi etu.

9. Omista erityistä huomiota asiantuntijatason henkilöstön valmiuksien kehittämiseen niiden kansainvälisten tietojärjestelmien hyväksikäyttöön, jotka palvelevat heidän asiantuntemuksensa karttumista. Huolehdi, että alan kirjallisuutta ja aika. kauskirja-aineistoa on asiantuntijoiden käytettävissä.

10.Luo henkilöstökoulutukseen sellainen viestintäjärjestelmä, että toiminnasta vastaavat henkilöt saavat aktiivista palautetta palveluksien käyttäjiltä.

Osaamisen tuottaminen työelämässä ei ole ongelmatonta. Vaikka kehittämishaluisia työntekijöitä ja asialle suopeita johtajiakin on, niin ajankäyttö asettaa usein rajoituksia toiminnalle. Ongelmallista on myös se, että resursseja sellaisen henkilöstökoulutuksen kannalta tarpeellisen tutkimuksen ja kehittämisen käyttöön on niukasti, joiden tarkoituksena olisi luoda uusia toimintamalleja aikuiskouluttajien käyttöön.

Opetusmuotoja, joiden luotettavuus ja toimivuus vastaisivat työelämässä hyvän koke. muksen hankkineiden ihmisten itsensä kehittämistarpeita, joudutaan jatkuvasti kehittä. mään. Tarvitaan kokeiluprojekteja, joissa nykyaikaiset tekniikan suomat mahdollisuudet ja aikuisen oppimisprosessin erityispiirteet pyrittäisiin sovittamaan yhteen työelämässä toimivan aikuisen elämänkäytäntöön.

On mahdollista, että tehty esitys sapattiva. paasta loisi uudenlaisia edellytyksiä kehittää 
sellaisia työelämässä kokemusta hankkineille soveltuvia itsensä kehittämismuotoja, jotka soveltuisivat vastaamaan uusia ulottuvuuksia kaipaavien aikuisten tarpeita.

\section{Henkilöstön kehittämisen asema organisaatiossa}

Henkilöstön kehittämisen merkityksen kasvun tulee näkyä myös organisaation ra. kenteessa. Henkilöstön kehittämisyksikköä ei enää edes julkishallinnossa saisi sijoittaa pieneksi saarekkeeksi "hallintotoimistoon", hallintohenkilöstön oman toimensa ohella hoidettavaksi tehtäväalueeksi. Kehittämishenkilöstön on oltava tehtäväänsä hyvin koulutettua asiantuntijahenkilöstöä ja heidän asemansa organisaatiossa tulee kuvastaa henkilöstön kehittämistoiminnan merkitystä.

Se toimintastrategia, että linjahallinto-organisaatiossa linjaesimiesten organisoimana esimerkiksi julkishallinnossa välittyisi asiantuntijahenkilöstölle selkeä kehittymisen mahdollisuus, on useimmiten vain kuvitel- ma. Linjaesimiehelle jätetty henkilöstön kehittämisvastuu ei usein edes hyvästä tahdos. ta huolimatta käytännössä toimi: arkikiireessä lyhyen tähtäimen tulostavoitteet on kovin inhimillistä asettaa pitkäjänteisen kehittämis. toiminnan edelle. Toiselta puolen on niin, että henkilöstön kehittämisestä vastuuta kantava johtaja on oiva kohde monenlaiselle kehittämispropagandalle. Asiantuntemus henkilöstökoulutuksen alueella auttaa organisaatiota usein välttymään hukkainvestoinnilta tälläkin alueella.

Asiantunteva henkilöstökouluttaja toimii organisaatiossa monella tapaa. Tehtäviin kuuluu toimia yhtä hyvin johtamistoimien edistäjänä kuin henkilöstöä lähellä olevana opintoneuvojana. Kehittämiseen erikoistunut henkilöstö on myös asiantuntija hyväksikäyttämään niitä koulutus- ja konsultointipalveluja, joita kehittyvä aikuiskoulutusjärjestel. mämme kasvavassa määrin tarjoaa. Kehittämishenkilöstö tulisikin sijoittaa organisaatiossa siten, että yhteys johtajistoon on vailla turhia väliportaita. Tällöin myös strategisesti tärkeä koulutus voidaan tuottaa mahdollisim. man pienellä viiveellä.

\section{LÄHTEET}

Anthony R. 1965. Planning and Control Systems: A Framework Analysis. New York.

Noe R.A. 1986. Trainees Attributes and Attitudes Neglected Influences on Training Effectiveness. Academys Of Management Review 11 (4) 736-749.

Vanhala S. 1980. Strategic Management of Human Resources. Helsingin kauppakorkeakoulu. Working Papers. F125. 